\title{
Turnera subulata Anti-Inflammatory Properties in Lipopolysaccharide-Stimulated RAW 264.7 Macrophages
}

\author{
Natália Cabral Souza, Juliana Medeiros de Oliveira, Maurílio da Silva Morrone, \\ Ricardo D'Oliveira Albanus, Maria do Socorro Medeiros Amarante, Christina da Silva Camillo, \\ Silvana Maria Zucolotto Langassner, Daniel Pens Gelain,2, José Cláudio Fonseca Moreira, \\ Rodrigo Juliani Siqueira Dalmolin, and Matheus Augusto de Bittencourt Pasquali ${ }^{1,5}$ \\ ${ }^{1}$ Institute of Tropical Medicine of Rio Grande do Norte, Federal University of Rio Grande do Norte, Natal, RN, Brazil. \\ ${ }^{2}$ Department of Biochemistry, Federal University of Rio Grande do Sul, Porto Alegre, RS, Brazil. \\ ${ }^{3}$ Department of Computational Medicine and Bioinformatics, University of Michigan, Ann Arbor, Michigan, USA. \\ ${ }^{4}$ Department of Morphology, Federal University of Rio Grande do Norte, Natal, RN, Brazil. \\ ${ }^{5}$ Department of Food Engineering, Federal University of Campina Grande, Campina Grande, PB, Brazil.
}

\begin{abstract}
In South America, particularly in the Northeastern regions of Brazil, Turnera subulata leaf extract is used as an alternative traditional medicine approach for several types of chronic diseases, such as diabetes, hypertension, chronic pain, and general inflammation. Despite its widespread use, little is known about the medicinal properties of the plants of this genus. In this study, we evaluate the antioxidant and anti-inflammatory of $T$. subulata leaf extract in an in vitro model of inflammation, using lipopolysaccharide-stimulated RAW-264.7 macrophage cell line. We observed that cotreatment with $T$. subulata leaf extract was able to reduce the oxidative stress in cells due to inflammatory response. More importantly, we observed that the leaf extract was able to directly modulate inflammatory response by altering activity of members of the mitogen-activated protein kinase pathways. Our results demonstrate for the first time that T. subulata have antioxidant and anti-inflammatory properties, which warrant further investigation of the medicinal potential of this species.
\end{abstract}

\section{KEYWORDS: • inflammation $\bullet$ oxidative stress $\bullet$ RAGE $\bullet T L R-4 \bullet$ Turnera subulata}

\section{INTRODUCTION}

$\mathbf{T}$ HE HEALTH BENEFITS of plant compounds acquired through the ingestion of tea, juice, fruits, and derivatives are an area of active research and have been approached by many different studies. In fact, the biological composition of these beverages and foods has been regarded as an important factor to reduce risk of chronic diseases. ${ }^{1-3}$ Moreover, with the development of new technologies to produce industrialized foods, the interest in consuming natural compounds that prove to be beneficial to human health has increased in last few years. Of particular note are the compounds with anticancer, antiinflammatory, and antioxidants properties, which have been extensively investigated in plant extracts and derivatives.

Turnera subulata is a tropical plant that occurs mainly in Northeastern Brazil. ${ }^{4}$ It is used in traditional medicine for treatment of different diseases, such as diabetes, hyperten-

Manuscript received 28 March 2016. Revision accepted 27 July 2016.

Address correspondence to: Matheus Augusto de Bittencourt Pasquali, MSc, PhD, Unidade de Engenharia de Alimentos, Universidade Federal de Campina Grande, Campina Grande, Paraíba 58109-900,Brazil, E-mail: matheuspasquali@gmail.com sion, chronic pain, and inflammation. ${ }^{5}$ Some authors have also reported aphrodisiacs and anxiolytic properties in plants of the genus Turnera. Characteristically, phenolic compounds, flavonoids, alkaloids, and tannins have been related as the main biological molecules of genus Turnera, which can be responsible for mediating biological activities in organisms (Table 1). ${ }^{6}$ Some reports have demonstrated the antioxidant effects of extracts obtained from Turnera species. ${ }^{7-9}$ However, the biological properties and effects of Turnera subulata leaf extract remain unknown.

Recently, studies have associated positive effects attributed to genus Turnera with higher concentrations of arbutin, a biological compound found in different parts of the plant. ${ }^{10-12}$ The decrease of cytokine secretion, such as TNF- $\alpha$, IL-1, and IL-6, observed in treatments with Turnera diffusa or Turnera ulmifolia in different models of in vivo inflammation was reported as positive effects of those plants. ${ }^{5,7,13,14}$ Moreover, the antioxidant properties of those extracts were demonstrated through the decreased lipoperoxidation and modulation of antioxidant enzymes such as glutathione peroxidase, superoxide dismutase (SOD), and catalase (CAT) in the liver of CCl4-treated rats. 
Table 1. Chemical Constituents Found in Extracts OF Genus TURNERA

\begin{tabular}{lc}
\hline & Chemical constituent \\
\hline Phenolic & Arbutin \\
Flavonoid & Luteolin \\
Flavonoid & Quercetin \\
Flavonoid & Apigenin \\
Flavonoid & Pinocembrin \\
Flavonoid & Syringetin \\
\hline
\end{tabular}

Principal chemical compounds found in different species of genus Turnera.

The role of reactive oxygen species (ROS) and reactive nitrogen species (RNS) in mechanisms that lead to pathological diseases are largely studied. It is known that ROS/ RNS is involved in normal signaling pathways and metabolic processes. ROS/RNS products, such as superoxide radical anion $\left(\mathrm{O}_{2}{ }^{-} \cdot\right)$, hydrogen peroxide $\left(\mathrm{H}_{2} \mathrm{O}_{2}\right)$, hydroxyl radical $(\mathrm{OH} \cdot)$, and nitric oxide, can trigger cells to proliferate and differentiate, and cell apoptosis and death. ${ }^{15-19}$ However, an imbalance in the organism between ROS/RNS production and antioxidant defenses can lead to a condition known as oxidative stress. ${ }^{20-22}$ Cancer, neurodegenerative diseases, diabetes, and cardiovascular diseases are pathological conditions that present oxidative stress in its etiology. Moreover, ROS/RNS also plays central involvement in activation and progression of inflammatory pathways. ${ }^{23,24}$ Due to the complex biological composition, the consumption of plants extracts has been largely recommended to prevent risk of diseases. In part, this is suggested as a result of antioxidant properties that extracts exhibit.

In this study, we investigated the antioxidant and antiinflammatory effects of leaf extract from Turnera subulata in an in vitro model of inflammation. We observed that leaf extracts exhibit antioxidant activities. Moreover, the extract was able to inhibit phosphorylation in mitogen-activated protein kinases (MAPKs) p38, ERK $1 / 2$, and JNK, which was mediated by lipopolysaccharide (LPS)-stimulated macrophages. Markers of macrophage response for inflammation such as toll-like receptor 4 (TLR4), receptor for advanced end glycation products (RAGE), and CD40 were also investigated. Secretion of cytokines TNF- $\alpha$ and IL- $1 \beta$ in the medium was measured. Leaf extract of Turnera subulata inhibited the effect mediated by LPS in our model of inflammation. Our data demonstrate for the first time the potential antiinflammatory and antioxidant effects of Turnera subulata.

\section{MATERIALS AND METHODS}

\section{Chemicals}

Culture analytical grade reagents were purchased from Sigma Chemical Co. (St.Louis, MO, USA). Antibodies against total and phospho-SAPK-JNK, total and phosphop38 MAPK, total and phospho-ERK, TLR4, and $\beta$-actin were all purchased from Cell Signaling (Beverly, MA, USA). Anti-RAGE and CD40 antibodies were purchased from AbCam (Cambridge, United Kingdom).

\section{Cell culture}

The mouse macrophage cell line RAW 264.7 was grown in RPMI-1640 and $10 \% \mathrm{FBS}$, and maintained at $37^{\circ} \mathrm{C}$ in an atmosphere containing $5 \% \mathrm{CO}_{2}$. The media were supplemented with $1 \%$ penicillin/streptomycin.

\section{Extract}

The leaves of Turnera subulata were collected in Parnamirim ( $5^{\circ} 55^{\prime} 21.0^{\prime \prime} \mathrm{S}-35^{\circ} 11^{\prime} 50.5^{\prime \prime} \mathrm{W}$ )-Rio Grande do Norte -Brazil. The plant material was identified by the Pharmacy Faculty Center of Federal University of Rio Grande do NorteUFRN-Brazil. Specimen from Turnera subulata was deposited at the Herbario do Departamento de Botânica, Ecologia e Zoologia of Federal University of Rio Grande do NorteUFRN-Brazil. To prepare extract, the leaves of Turnera subulata were air-dried at $40^{\circ} \mathrm{C}$, powdered, and extracted by infusion with boiling water $\left(95^{\circ} \mathrm{C}\right.$, plant solvent $\left.1: 10, \mathrm{~g} / \mathrm{mL}\right)$ for $10 \mathrm{~min}$. The aqueous extract was filtered, lyophilized, and stored at $-80^{\circ} \mathrm{C}$ until tested.

\section{Treatments}

The extract was dissolved in a medium. Concentrated stocks were prepared immediately before experiments by dissolving extract into the medium and solution was kept protected from light and high temperatures during all procedures. Cells were treated with different concentrations of extract $(0.5,5,500 \mu \mathrm{g} / \mathrm{mL})$. All treatments were initiated by adding concentrated solutions to reach final concentrations in the well.

\section{Thiobarbituric acid-reactive species}

The cells were plated onto flasks of $25 \mathrm{~cm}^{2}$.After $24 \mathrm{~h}$ of treatment, the cells were collected and homogenized. As an index of lipid peroxidation, we measured the formation of thiobarbituric acid-reactive species (TBARS) during an acid-heating reaction, which is widely adopted for measurement of lipid redox state, as previously described. ${ }^{25}$

\section{Measurement of protein carbonyls}

Cells were plated onto flasks of $25 \mathrm{~cm}^{2}$. After $24 \mathrm{~h}$ of treatment, the cells were collected and homogenized. The oxidative damage to proteins was measured by the quantification of carbonyl groups based on the reaction with dinitrophenylhydrazine as previously described. ${ }^{26}$

\section{Measurement of protein thiol content}

The cells were plated onto flasks of $25 \mathrm{~cm}^{2}$. After $24 \mathrm{~h}$ of treatment, the cells were collected and homogenized. Protein thiol content in samples was analyzed to estimate oxidative alterations in proteins. ${ }^{27}$

\section{Estimation of antioxidant enzyme activities}

The cells were plated onto flasks of $25 \mathrm{~cm}^{2}$. After $24 \mathrm{~h}$ of treatment, the cells were collected and homogenized. The 
catalase (EC 1.11.1.6) (CAT) activity was assayed by measuring the rate of decrease in $\mathrm{H}_{2} \mathrm{O}_{2}$ absorbance in a spectrophotometer at $240 \mathrm{~nm}$, and the results are expressed as units of CAT/mg of protein. ${ }^{28}$ The SOD (EC 1.15.1.1) activity was assessed by quantifying the inhibition of superoxide-dependent adrenaline autoxidation in a spectrophotometer at $480 \mathrm{~nm}$, as previously described, and the results are expressed a units of SOD/mg of protein. ${ }^{29}$

\section{Determination of intracellular RS production (real-time dichlorofluorescein oxidation assay)}

Intracellular reactive species production was determined by the DCFH-DA-based real-time assay using intact living cells. Briefly, RAW 264.7 cells were plated onto 96-well plates and incubated for $1 \mathrm{~h}$ with DCFH-DA $100 \mu \mathrm{M}$ (stock solution in DMSO, $10 \mathrm{mM}$ ) in $1 \%$ FBS culture medium at $5 \% \mathrm{CO}_{2}$ and $37^{\circ} \mathrm{C} .{ }^{30}$ Cells were then washed and treatments were carried out. During treatment, changes in the fluorescence by the oxidation of DCFH into the fluorogen DCF were monitored in a microplate fluorescence reader (F2000, Hitachi Ltd., Tokyo, Japan) for $1 \mathrm{~h}$ at $37^{\circ} \mathrm{C}$.

\section{MTT assay}

The cells were plated onto 96-well plates. When the culture reached $60 \%$ confluence, the culture medium of the RAW 264.7 cells was removed and the treatments were added. After $24 \mathrm{~h}$ of leaf extract treatment, RAW 264.7 cell viability was assessed by the MTT assay. ${ }^{31} \mathrm{H}_{2} \mathrm{O}_{2} 300 \mu \mathrm{M}$ was used as positive control for cell death.

\section{Sulforhodamine B assay}

This colorimetric assay was performed to assess growth. It estimates cell numbers indirectly by staining total cellular protein with sulforhodamine B (SRB). ${ }^{32}$

\section{Immunoblot}

To perform immunoblot experiments, RAW 264.7 cells were lysed in Laemmli sample buffer $(62.5 \mathrm{mM}$ Tris- $\mathrm{HCl}$, $\mathrm{pH} 6.8,1 \%[\mathrm{w} / \mathrm{v}]$ SDS, $10 \%[\mathrm{v} / \mathrm{v}]$ glycerol) and equal amounts of cell protein $(30 \mu \mathrm{g} / \mathrm{well})$ were fractionated by SDS-PAGE and electroblotted onto nitrocellulose membranes. Protein loading and electroblotting efficiency were verified through Ponceau S staining, and the membrane was blocked in Tween-Tris-buffered saline (TTBS: $100 \mathrm{mM}$ Tris-HCl, pH 7.5, containing $0.9 \% \mathrm{NaCl}$ and $0.1 \%$ Tween 20) containing $5 \%$ albumin. Membranes were incubated overnight at $4^{\circ} \mathrm{C}$ with antibodies in the presence of $5 \%$ skim milk and then washed with TTBS. Anti-rabbit IgG peroxidase-linked secondary antibody was incubated with the membranes for an additional $1 \mathrm{~h}$ (1:5000 dilution range), washed again, and the immunoreactivity was detected by enhanced chemiluminescence using the ECL Plus kit. Densitometric analysis of the films was performed with Image $\mathbf{J}$ software. Blots were developed to be linear in the range used for densitometry.

\section{Indirect ELISA}

TNF- $\alpha$ was quantified by indirect ELISA. A 96-well ELISA plate was coated with $200 \mu \mathrm{L}$ of culture medium and purified recombinant TNF- $\alpha$ protein (Abcam-Cambridge, United Kingdom) diluted in $50 \mathrm{mM}$ carbonate buffer, $\mathrm{pH} 9.0$, for standard curve calculation. After $24 \mathrm{~h}$ of incubation, plates were washed thrice with TTBS $(100 \mathrm{mM}$ Tris- $\mathrm{HCl}$, pH 7.5, containing $0.9 \% \mathrm{NaCl}$, and $0.1 \%$ Tween-20). Subsequently, $200 \mu \mathrm{L}$ of anti-TNF $\alpha$ (1:8000 dilution range) was added and incubation was carried for $24 \mathrm{~h}$ at $4^{\circ} \mathrm{C}$. The plate was washed thrice with TTBS and incubated with $200 \mu \mathrm{L}$ of a rabbit IgG peroxidase-linked secondary antibody (1:7000 dilution range) for $2 \mathrm{~h}$. After washing the plate thrice with TTBS, $200 \mu \mathrm{L}$ of substrate solution (TMB spectrophotometric ELISA detection kit) was added to each well and incubated for $15 \mathrm{~min}$. The reaction was terminated with $50 \mu \mathrm{L} /$ well of $12 \mathrm{M}$ sulfuric acid stopping reagent and the plate read at $450 \mathrm{~nm}$. IL- $1 \beta$ was detected by Abcam IL-1 beta Mouse ELISA (Enzyme-Linked Immunosorbent Assay) kit Immunoassay Kit following the manufacturer's instructions.

\section{Statistical analysis}

Results are expressed as mean value \pm standard error of the mean; $P$-values were considered significant when $P<.05$. Differences in experimental groups were determined by one-way ANOVA followed by the post-hoc Tukey's test whenever necessary.

\section{RESULTS}

We first analyzed the viability of cells treated with leaf extracts at the concentration of $0.5,5$, and $500 \mu \mathrm{g} / \mathrm{mL}$ (Fig. 1). We observed that all treatments did not alter cell viability, as indicated by MTT and SRB-based assays. We also analyzed the effects of leaf extract when used in cotreatment during inflammatory response mediated in macrophage cells through LPS treatment at $1 \mu \mathrm{g} / \mathrm{mL}$. At all concentrations of $0.5,5$, and $500 \mu \mathrm{g} / \mathrm{mL}$, cotreatment with leaf extract blocked the effect mediated by LPS in viability of macrophages (Fig. 1).

The antioxidant properties were evaluated by measuring parameters of oxidative stress in macrophage cells treated with different concentrations of leaf extract for $24 \mathrm{~h}$. The extract, when used alone in macrophage cells, did not alter the levels of lipid peroxidation. However, in LPS-induced macrophage cells, we observed decreased lipid peroxidation levels in macrophage cells that received leaf extract cotreatment (Fig. 1). Moreover, these effects observed were dose dependent. The protein carbonylation levels also were evaluated. The treatment with extract did not alter the levels of protein carbonylation in macrophage cells. Similar to effects observed in lipid peroxidation, the cotreatment with extract in LPS-induced macrophage cells blocked the increase in protein carbonylation levels (Fig. 1). Interestingly, protein thiol content was not altered by leaf extract treatment. However, cotreatments in LPS-induced macrophage cells 
blocked the effect mediated by LPS in protein thiol content (Fig. 1).

The activity of antioxidant enzymes was altered by leaf extract treatment. We observed a decrease in CAT and SOD activities in cells treated with leaf extract (Fig. 1) alone. In LPS-induced macrophage cells, the cotreatment with leaf extract blocked effects in CAT and SOD activities (Fig. 1). In addition, the effects observed in antioxidant enzymes activities were dose dependent (Fig. 1). Together, these data indicate that leaf extract of Turnera subulata presents antioxidant properties that result in the modulation of redox parameters induced by LPS.

To confirm antioxidant properties of leaf extract, we evaluated the production of ROS/RNS in macrophage cells treated with leaf extract using real-time DCFH oxidation assay. We observed that leaf extract at all concentrations inhibited cellular ROS/RNS production (Fig. 1). To confirm these antioxidant properties of the leaf extract, we cotreated LPS-induced macrophage cells and the rate of intracellular reactive species production was evaluated by DCF fluorescence. Once more, leaf extract treatment exhibits antioxidant properties (Fig. 2H), which were responsible for decreased ROS/RNS detection in the DCFH assay. Together, these results demonstrate that leaf extract was efficiently able to reduce cellular ROS/RNS production and prevent increase in ROS/RNS levels when the cells are exposed to oxidative stress conditions.

ROS/RNS is involved in the genesis of inflammatory response. Due to the cellular signaling pathways that could be affected by the oxidative stress during inflammatory response, we decided to investigate the effects of leaf extract in MAPKs, which are a family of proteins involved in inflammatory response signaling. We analyzed the effects of Turnera subulata leaf extract in inflammatory response, mediated in macrophage cells through LPS treatment, on the activation state of MAPK ERK 1/2, SAPK/JNK, and p38. MAPK phosphorylation is generally triggered within few minutes after cell stimulation; so we preincubated macrophage cells with leaf extract at different doses for $60 \mathrm{~min}$ and then LPS at $1 \mu \mathrm{g} / \mathrm{mL}$ was added to cells. Subsequently, we performed immunoblots to detect the phosphorylated (i.e., active) forms of these protein kinases. It is known that LPS treatment stimulates ERK 1/2, JNK, and p38 phosphorylation within few minutes. ERK $1 / 2$ phosphorylation steadily increased with time and peaked at $60 \mathrm{~min}$, while p38 and JNK activation peaked at $30 \mathrm{~min}$ of incubation. Turnera subulata leaf extract cotreatment at the concentration $500 \mu \mathrm{g} / \mathrm{mL}$ inhibited the LPS-induced phosphorylation of ERK 1/2 (Fig. 2). In p38 (Fig. 2), no changes were observed in the activation states in macrophage cells that were cotreated with leaf extracts. Similar behavior was observed in SAPK/JNK activation (Fig. 2). These results indicate that Turnera subulata leaf extract was able to block effects in LPS-induced cells only through ERK $1 / 2$ activation states. The other members of MAPK proteins evaluated in this study were not modulated by Turnera subulata treatments.

During cellular response induced by LPS treatment, there occurs secretion of cytokines, such as TNF- $\alpha$ and IL- $1 \beta$.
These cytokines regulate critical cellular processes, such as apoptosis, inflammation, and proliferation. In this study, we observed that cotreatment at $500 \mu \mathrm{g} / \mathrm{mL}$ of Turnera subulata leaf extract reduced the secretion of both TNF- $\alpha$ and IL- $1 \beta$ (Fig. 3) in LPS-induced macrophages cells. The other concentration used in cotreatment did not block TNF- $\alpha$ and IL$1 \beta$ secretion mediated by LPS. In macrophages, TLR 4 can be modulated by LPS treatment. In addition, it is also known that RAGE and CD40 have their expression modulated during an inflammatory process induced by LPS. Therefore, we decided to investigate the immunocontent of these receptors in cells treated with LPS and cotreated with Turnera subulata leaf extract. We found that cotreatment with leaf extract did not inhibit the increase of TLR 4 mediated by LPS treatment (Fig. 3). However, the effects mediated by LPS in RAGE and CD40 immunocontent were inhibited through cotreatment with Turnera subulata leaf extract at $500 \mu \mathrm{g} / \mathrm{mL}$ of concentration. Taken together, these data indicate that the Turnera subulata leaf extract used in our study have anti-inflammatory properties. In addition, the results found in this study suggests that the action of the leaf extract could be triggered by ERK $1 / 2$ inactivation.

\section{DISCUSSION}

The role of plants extract exerts in traditional medicine has been largely studied. The anticancer, anti-inflammatory, and antioxidant properties of diverse extracts have been associated to innumerous secondary metabolites found in different parts of the plants. The beneficial effects described for these molecules have stimulated the use of natural plant products in nutritional supplements. In addition, innumerous authors have suggested the positive relationship in consumption of natural products and decrease of risk of chronic diseases. ${ }^{33-35}$ In these lines, the use of plant extracts has represented along the years, a promising tool to prevent and decrease the onset of chronic diseases.

In this study, our work demonstrates antioxidant and antiinflammatory effects that leaf extract of Turnera subulata exhibited when used in a model of in vitro inflammation. Leaf extract decreased lipid peroxidation and protein carbonylation, which was demonstrated through dose-dependent effects during LPS-induced treatment. In addition, activities of CAT and SOD were also modulated by leaf extract of Turnera subulata, principally in LPS-induced model. Authors recently described that the genus Turnera is a source of different secondary compounds, such as phenolic, alkaloids, cyanogenic glycosides, steroids, saponins, and flavonoids that are likely associated with the positive effects of plant products. ${ }^{6,36,37}$ Some of these compounds can exhibit higher antioxidant activities, which in almost all studies are suggested to be used to reduce ROS/RNS production in biological systems.

The antioxidant properties of secondary metabolites of plants can be exerted by different mechanisms. Authors have shown that compounds found in plants can act as reducing agents, scavengers of free radicals, metal ion chelators, cofactors of enzymes catalyzing oxidative reactions, inhibitors 


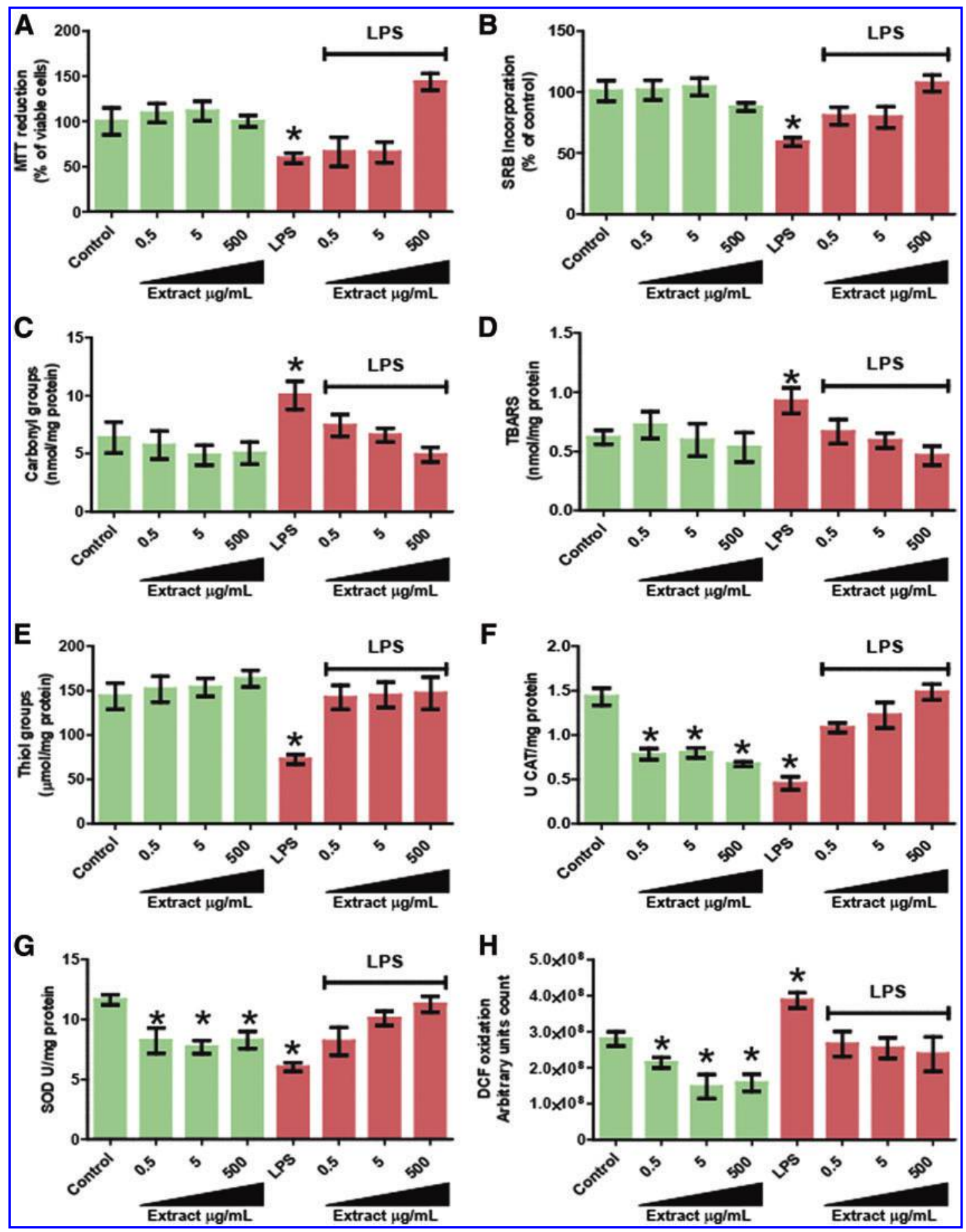

FIG. 1. Parameters of cell viability and oxidative stress in RAW 264.7 cells treated with Turnera subulata leaf extract for $24 \mathrm{~h}$ and in RAW 264.7 cells lipopolysaccharide(LPS) stimulated $(1 \mu \mathrm{g} / \mathrm{mL})$ and cotreated with Turnera subulata leaf extract for $24 \mathrm{~h}$. RAW 264.7 cells were treated with leaf extract at $0.5,5$, and $500 \mu \mathrm{g} / \mathrm{mL}$. Different assays were performed to evaluate cell viability after incubation; LPS (1 $\mu \mathrm{g} / \mathrm{mL}) \mathrm{was}$ used as a positive control for loss of viability. (A) MTT reduction assay and (B) SRB-incorporation assay. Parameters of oxidative stress: (C) carbonyl levels were quantified to evaluate cell protein oxidative damage; (D) thiobarbituric acid reactive species (TBARS) levels were assessed as an index for cellular lipid peroxidation; and (E) thiol levels were assessed to verify protein redox modification. The activities of the antioxidant enzymes (F), catalase (CAT), and (G) superoxide dismutase (SOD) were also evaluated. Intracellular reactive species production by RAW 264.7 cells subjected to leaf extract treatment was evaluated. $(\mathbf{H})$ Cells were treated with different concentrations of leaf extract for $1 \mathrm{~h}$ and the total production of reactive species by living cells was evaluated by the real-time DCFH oxidation assay; LPS ( $1 \mu \mathrm{g} / \mathrm{mL})$ was used as a positive control for reactive species production and fluorescence intensity was calculated relative to control cells. Control group is represented in all graphs by "Control." Data represent mean \pm SEM from three independent experiments ( $n=6$ per group). One-way ANOVA followed by the post hoc Tukey's test, ${ }^{*} P<.05$ versus the control group. SRB, sulforhodamine B. SEM, standard error of the mean. Color images available online at www.liebertpub.com/jmf 


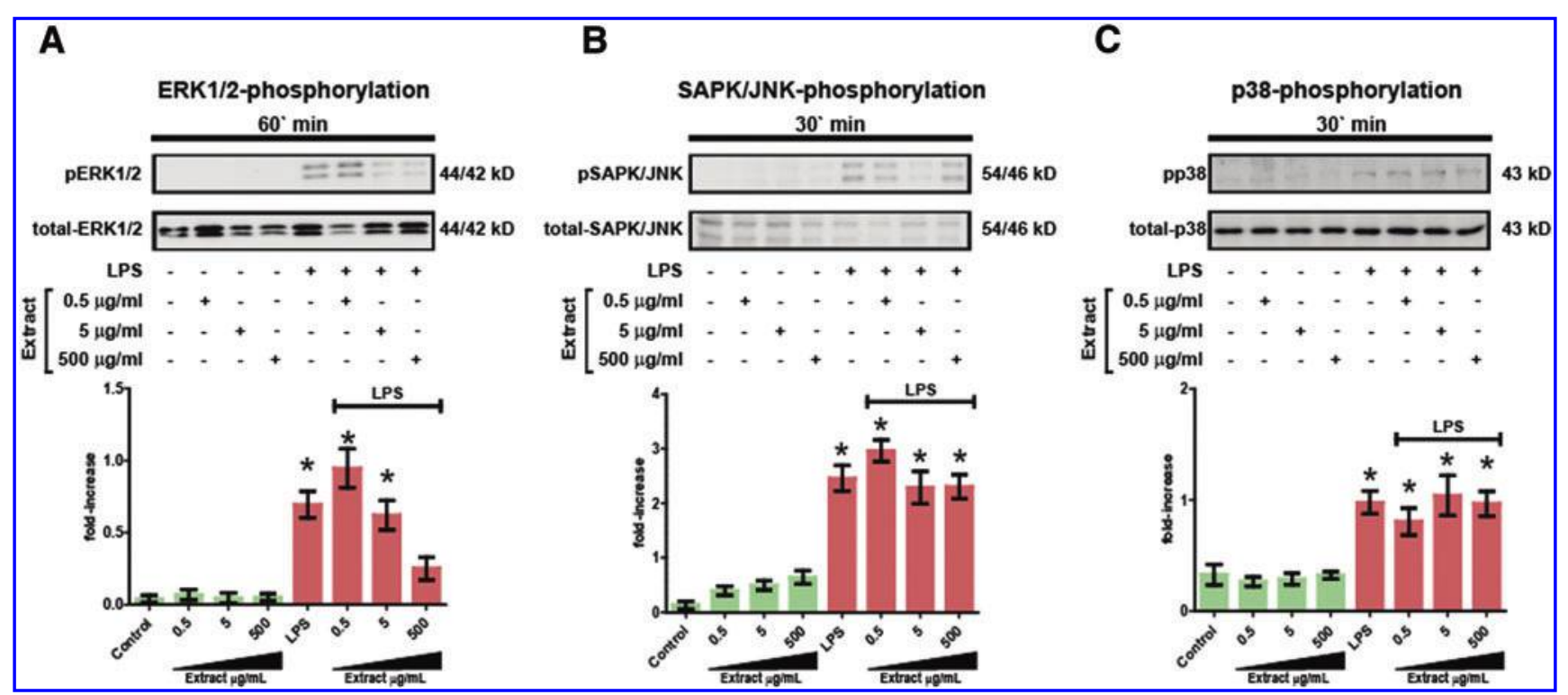

FIG. 2. Effect of Turnera subulata leaf extract preincubation $(0.5$, and $5 \mu \mathrm{g} / \mathrm{mL})$ on the phosphorylation of (A) EKR $1 / 2(60 \mathrm{~min})$, (B) SAPK/JNK (30 min), and (C) p38 (30 min), in RAW 264.7 cells and RAW 264.7 LPS stimulated. Representative images (Western blots) reveal detection of phosphorylated isoforms of EKR $1 / 2, \mathrm{SAPK} / \mathrm{JNK}$, and $\mathrm{p} 38$. Graphs exhibit the relative quantification of phosphorylated isoforms of EKR $1 / 2$, SAPK/ JNK, and p38 in relationship to their total immunocontent. Data represent mean \pm SEM from three independent experiments $(n=3$ per group). Oneway ANOVA followed by the post hoc Tukey's test, $* P<.05$ versus the control group. Color images available online at www.liebertpub.com/jmf

of oxidases, terminators of radical chain reactions, and stabilizers of free radicals..$^{38-41}$ To reinforce these findings, it is known that phenolic compounds are associated with a decrease in $\mathrm{O}_{2}{ }^{-}$. production. ${ }^{42-44}$ Furthermore, they are able to inhibit $\mathrm{OH}$ - formation in a system containing iron and hydrogen peroxide $\left(\mathrm{H}_{2} \mathrm{O}_{2}\right)$ through the Fenton reaction. ${ }^{45,46}$ In this study, we demonstrated that leaf extract of Turnera subulata was able to reduce the lipid peroxidation and protein carbonylation in LPS-induced macrophages. LPS treatment is known for upregulating both $\mathrm{O}_{2}^{-}$. and $\mathrm{OH} \cdot$ production in macrophage cells. Therefore, our findings suggest that leaf extract exerted an antioxidant effect and these effects could be associated to secondary compounds present in leaf extract. Besides, their actions may be mediated through the synergistic action of these biological compounds.

The capacity of genus Turnera to modulate enzymes through inhibition/activation has been reported in different studies. It is known that Turnera diffusa extract had properties to inhibit aromatase enzyme. Most of this effect was associated with higher flavonoid content in the extract. ${ }^{12}$ However, the effects of genus Turnera in modulating antioxidant enzymes responsible for the decrease in ROS/RNS are unclear. Interestingly, we found that leaf extract of Turnera subulata was able to modulate antioxidant enzyme activities, such as CAT and SOD activities, in macrophages cells. These effects were more clear in LPS-induced macrophage cells. It is well described that LPS treatment in macrophage cells leads to an impairment of the electron transfer system, thus increasing the rate of $\mathrm{O}_{2}{ }^{-}$. production. ${ }^{47-49}$ In this study, our results confirmed the increased SOD activity and $\mathrm{O}_{2}^{-}$. production during LPS-induced treatment in macrophage cells. Moreover, we observed a decrease in the CAT activity. In these terms, it is well de- scribed that $\mathrm{O}_{2}^{-}$. is a potent inhibitor of CAT..$^{50,51}$ The cotreatment with Turnera subulata inhibited the decrease in CAT and SOD activities of LPS-induced macrophage cells. These effects corroborate with data found in lipid peroxidation and protein carbonylation, where leaf extract showed antioxidant properties during cotreatment. It is known that a large portion of biological properties and functions involving protein structure, enzyme catalysis, and redox signaling pathways depends on the redox state of the cells. The latter can trigger the cells during proliferation, differentiation, and/or inflammation. ${ }^{52,53}$ Moreover, innumerous reports have demonstrated that the increase in protein carbonylation may be involved in the formation of protein aggregates, which are very likely to culminate in widespread cellular dysfunction. ${ }^{54}$ The increased damage to proteins might result in increased free iron, because of its release from damaged ferritin and other iron-containing proteins, favoring the maintenance of the pro-oxidative state. The correlation between protein damage and inflammatory response is related with the increase of ROS/RNS production that occurs during inflammatory response. The decrease in ROS/ RNS production is associated with the anti-inflammatory response, and biological molecules that present activities to inhibit the ROS/RNS production are target of recent studies. ${ }^{55-57}$ In this study, we found that the leaf extract of Turnera subulata was able to reduce damage in proteins and lipids in macrophage cells subjected to LPS treatment. The inhibition of damage in biological molecules might contribute to maintenance of structure and function of proteins and lipids, which in turn leads to the anti-inflammatory response in the organism. ${ }^{58-61}$

During proinflammatory response occurs characteristically the release of cytokines, such as IL- $1 \beta$ and TNF- $\alpha$. 


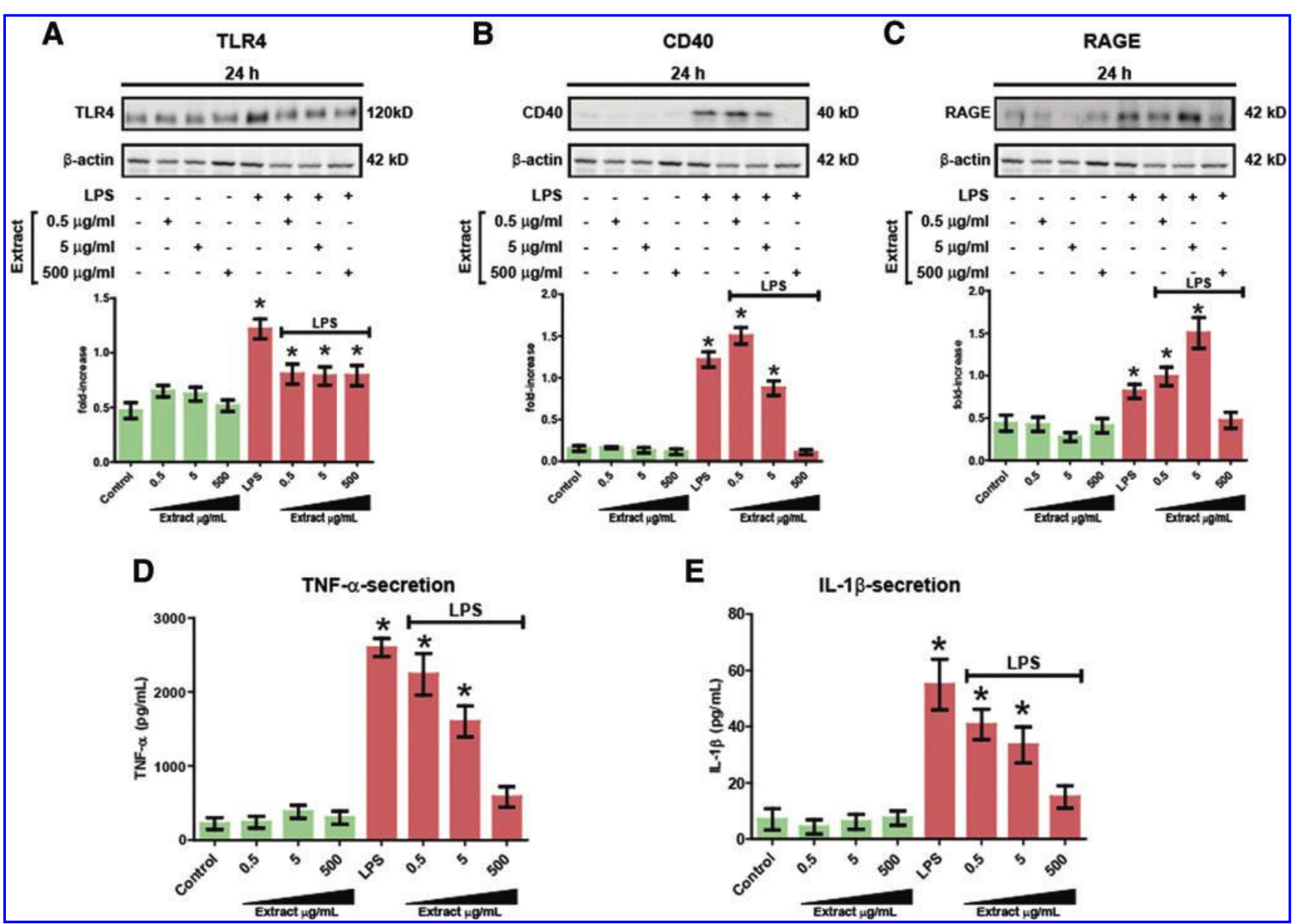

FIG. 3. Effect of Turnera subulata leaf extract $(0.5$, and $5 \mu \mathrm{g} / \mathrm{mL})$ on the inflammatory biomarkers and cytokine release. (A) TLR-4, (B) CD40, and (C) RAGE immunocontent in RAW 264.7 cells and RAW 264.7 LPS stimulated after 24h. Representative images (Western blots) reveal detection of immunocontent of proteins in total cell homogenates. Graphs exhibit the relative quantification of immunocontent of protein in relationship to their $\beta$-actin total immunocontent. (D) TNF- $\alpha$ and (E) IL- $1 \beta$ content in medium of incubation. Release of cytokines was performed by ELISA. Data represent mean \pm SEM from three independent experiments ( $n=3$ per group for Western blotting, and $n=6$ per group to ELISA assays). One-way ANOVA followed by the post hoc Tukey's test, $* P<.05$ versus the control group. RAGE, receptor for advanced end glycation products. Color images available online at www.liebertpub.com/jmf

$\mathrm{IL}-1 \beta$ is an important mediator involved in the inflammatory response of cells. ${ }^{62,63}$ Here, our study demonstrated that cotreatment with leaf extract of Turnera subulata induces inhibition of IL- $1 \beta$ secretion by LPS-induced macrophages. Interestingly, cotreatment with leaf extract did not inhibit the increase in TLR4 immunocontent. It is known that LPS treatment induces the expression of TLR4 and expression of this receptor is associated with inflammatory response. The class of TLR receptors is involved in activation of different cellular pathways that regulate the expression of cytokines, including IL- $1 \beta{ }^{64} \mathrm{TNF}-\alpha$ secretion was also inhibited by the leaf extract cotreatment. TNF- $\alpha$ is known for regulating proinflammatory responses in different cells, such as endothelial cells, and contributes to an increase of ROS/RNS production in immune system cells involved in inflammatory response. ${ }^{65}$ The involvement of CD40 in inflammation is well-known, as it is responsible for regulating different pathways involved in the expression of cytokines such as TNF- $\alpha$ and IL- $1 \beta{ }^{66}$ In this study, our results showed that leaf extract cotreatment was able to inhibit the expression of
CD40 and RAGE in LPS-induced macrophage cells. Taken together, our results demonstrate that leaf extract of Turnera subulata have anti-inflammatory properties.

The leaf extract cotreatment also inhibited the phosphorylation of ERK $1 / 2$. The association of MAPK signaling pathways during inflammatory response has been demonstrated in numerous reports; moreover, transient MAPK activation is associated with cell proliferation, whereas prolonged MAPK activation may be involved in promoting cell death. Previous works have shown the involvement of MAPK activation in regulatory mechanisms of RAGE, CD $40, \mathrm{TNF}-\alpha, \mathrm{IL}-1 \beta$, and TLR4 expression in LPS-induced models. ${ }^{67}$ In part, LPS treatment effects in MAPKs can be mediated through the involvement of ROS/RNS. MAPK activation can stimulate different transcript factors such as nuclear factor kappa B (NF$\kappa \mathrm{B})$, nuclear E2-related factor 2 ( $\mathrm{Nrf} 2)$, and $\mathrm{p} 53$, which are classically known for their ubiquitous roles in inflammatory, immune, and stress-related responses, and regulation of cell survival in all tissues ${ }^{68}$ Inhibition of MAPK phosphorylation mediated by LPS has been suggested as an anti-inflammatory 
mechanism for different biological compounds in numerous studies. These effects, at least in part, are due to MAPK signaling blocking, which in turn leads to inhibition of transcription factor activation such as NF- $\kappa \mathrm{B}$ and decrease in the cytokine expression in macrophages and other cells of immune system. ${ }^{69}$ Therefore, our results strongly indicate that leaf extract of Turnera subulata has the capacity of modulating MAPK signaling pathways. We speculate that inhibition of ERK $1 / 2$ phosphorylation mediated by leaf extract was able to block the inflammatory response in macrophage cells. The same dose of leaf extract that inhibited the ERK $1 / 2$ phosphorylation in LPS-induced macrophages, also blocked the increase in RAGE and CD40 immunocontent and reduced the secretion of TNF- $\alpha$ and IL- $1 \beta$.

In conclusion, the results presented in this study demonstrate for the first time that the leaf extract of Turnera subulata presents antioxidant and anti-inflammatory properties. Moreover, the data reinforce the importance of potential health benefits that the consumption of plants of genus Turnera may promote. Our findings may also be useful for better comprehension of the properties and mechanism of action mediated by Turnera compounds.

\section{ACKNOWLEDGMENTS}

This work was funded by National Counsel of Technological and Scientific Development (CNPq) (grants: 400805/ 2014-6, 444856/2014-5, 443514/2014-3, and 467393/2014-1). Matheus Augusto de Bittencourt Pasquali received fellowship from CNPq.

\section{AUTHOR DISCLOSURE STATEMENT}

No competing financial interests exist.

\section{REFERENCES}

1. Dauchet L, Amouyel P, Hercberg S, Dallongeville J: Fruit and vegetable consumption and risk of coronary heart disease: A meta-analysis of cohort studies. J Nutr 2006;136:2588-2593.

2. Tohill BC, Seymour J, Serdula M, Kettel-Khan L, Rolls BJ: What epidemiologic studies tell us about the relationship between fruit and vegetable consumption and body weight. Nutr Rev 2004;62:365-374.

3. Cooke LJ, et al.: Demographic, familial and trait predictors of fruit and vegetable consumption by pre-school children. $\underline{\text { Public }}$ Health Nutr 2004;7:295-302.

4. de Carvalho Nilo Bitu V. et al.: Ethnopharmacological study of plants sold for therapeutic purposes in public markets in Northeast Brazil. J Ethnopharmacol 2015;172:265-272.

5. Brito NJN, et al.: Antioxidant activity and protective effect of Turnera ulmifolia Linn. var. elegans against carbon tetrachlorideinduced oxidative damage in rats. Food Chem Toxicol 2012;50: 4340-4347.

6. Kumar S, Taneja R, Sharma A: The genus Turnera: A review update. Pharm Biol 2005;43:383-391.

7. Estrada-Reyes R, Carro-Juárez M, Martínez-Mota L: Pro-sexual effects of Turnera diffusa Wild (Turneraceae) in male rats involves the nitric oxide pathway. J Ethnopharmacol 2013;146: 164-172.

8. Soriano-Melgar LDAA, et al:: Antioxidant and trace element content of damiana (Turnera diffusa Willd) under wild and cultivated conditions in semi-arid zones. Ind Crops Prod 2012;37: 321-327.

9. Garza-Juárez A, Salazar-Cavazos MDLL, Salazar-Aranda R, Pérez-Meseguer J, de Torres NW: Correlation between chromatographic fingerprint and antioxidant activity of Turnera diffusa (Damiana). Planta Med 2011;77:958-963.

10. Takebayashi $\mathrm{J}$, et al.: Reassessment of antioxidant activity of arbutin: Multifaceted evaluation using five antioxidant assay systems. Free Radic Res 2010;44:473-478.

11. Avelino-Flores MDC, Cruz-López M. del C, Jiménez-Montejo FE, Reyes-Leyva J: Cytotoxic activity of the methanolic extract of Turnera diffusa Willd on breast cancer cells. $\mathrm{J} \mathrm{Med} \mathrm{Food}$ 2015;18:299-305.

12. Zhao J, Dasmahapatra AK, Khan SI, Khan IA: Anti-aromatase activity of the constituents from damiana (Turnera diffusa). $\underline{J}$ Ethnopharmacol 2008;120:387-393.

13. Galvez J, et al.: Intestinal antiinflammatory activity of a lyophilized infusion of Turnera ulmifolia in TNBS rat colitis. Fitoterapia 2006;77:515-520.

14. Szewczyk K, Zidorn C: Ethnobotany, phytochemistry, and bioactivity of the genus Turnera (Passifloraceae) with a focus on damiana-Turnera diffusa. J Ethnopharmacol 2014;152:424-443.

15. Huang J, Lam GY, Brumell J: Autophagy signaling through reactive oxygen species. Antioxid Redox Signal 2011;14:22152231.

16. Liu Z, Lenardo MJ: Reactive oxygen species regulate autophagy through redox-sensitive proteases. Dev Cell 2007;12:484-485.

17. Vernon PJ, Tang D: Eat-Me: Autophagy, phagocytosis, and reactive oxygen species signaling. Antioxid Redox Signal 2012;18: 120918063726003.

18. Azad MB, Chen Y, Gibson SB: Regulation of autophagy by reactive oxygen species (ROS): Implications for cancer progression and treatment. Antioxid Redox Signal 2009;11:777-790.

19. Chen Y, Azad MB, Gibson SB: Superoxide is the major reactive oxygen species regulating autophagy. Cell Death Differ 2009; 16:1040-1052.

20. Gutteridge JM, Halliwell B: Free radicals and antioxidants in the year 2000. A historical look to the future. Ann N Y Acad Sci 2000;899:136-147.

21. Fang YZ, Yang S, Wu G: Free radicals, antioxidants, and nutrition. Nutrition 2002;18:872-879.

22. Halliwell B: Free radicals, antioxidants, and human disease: Curiosity, cause, or consequence? Lancet 1994;344:721-724.

23. Mittal M, Siddiqui MR, Tran K, Reddy SP, Malik AB: Reactive oxygen species in inflammation and tissue injury. Antioxid Redox Signal 2014;20:1126-1167.

24. Khodr B, Khalil Z: Modulation of inflammation by reactive oxygen species: Implications for aging and tissue repair. Free Radic Biol Med 2001;30:1-8.

25. Draper HH, et al.: A comparative evaluation of thiobarbituric acid methods for the determination of malondialdehyde in biological materials. Free Radic Biol Med 1993;15:353-363.

26. Levine RL, et al.: Determination of carbonyl content in oxidatively modified proteins. Methods Enzymol 1990;186:464-478.

27. Ellman GL: Tissue sulfhydryl groups. Arch Biochem Biophys 1959;82:70-77. 
28. Aebi H: Catalase in vitro. Methods Enzymol 1984;105:121-126.

29. Misra Hara P, Fridovich I: The role of superoxide anion in the autoxidation of epinephrine and a simple assay for superoxide dismutase. J Biol Chem 1972;247:3170-3175.

30. Wang H, Joseph JA: Quantifying cellular oxidative stress by dichlorofluorescein assay using microplate reader. Free Radic Biol Med 1999;27:612-616.

31. De Bittencourt Pasquali MA, et al.: Vitamin A (retinol) downregulates the receptor for advanced glycation endproducts (RAGE) by oxidant-dependent activation of p38 MAPK and NF-kB in human lung cancer A549 cells. Cell Signal 2013;25: 939-954.

32. Skehan $\mathrm{P}$, et al.: New colorimetric cytotoxicity assay for anticancer-drug screening. J Natl Cancer Inst 1990;82:1107-1112.

33. Mukhtar M, et al.: Antiviral potentials of medicinal plants. Virus Res 2008;131:111-120.

34. Halliwell B: Oxidative stress, nutrition and health. Experimental strategies for optimization of nutritional antioxidant intake in humans. Free Radic Res 1996;25:57-74.

35. López-Alarcón C, Denicola A: Evaluating the antioxidant capacity of natural products: A review on chemical and cellularbased assays. Anal Chim Acta 2013;763:1-10.

36. Speranza PR, Seijo JG, Grela IA, Sol Neffa VG: Chloroplast DNA variation in the Turnera sidoides L. complex (Turneraceae): Biogeographical implications. J Biogeogr 2007;34:427-436.

37. Szewczyk K, Zidorn C: Ethnobotany, phytochemistry, and bioactivity of the genus Turnera (Passifloraceae) with a focus on damiana-Turnera diffusa. J Ethnopharmacol 2014;152:424443.

38. Rice-Evans Ca, Miller NJ, Paganga G: Antioxidant properties of phenolic compounds. Trends Plant Sci 1997;2:152-159.

39. Rice-Evans C, Miller N, Paganga G: Antioxidant properties of phenolic compounds. Trends Plant Sci 1997;2:152-159.

40. Miller NJ, Rice-Evans CA: Factors influencing the antioxidant activity determined by the ABTS.+ radical cation assay. Free Radic Res 1997;26:195-199.

41. Ruiz-Larrea MB, et al.: Antioxidant activity of phytoestrogenic isoflavones. Free Radic Res 1997;26:63-70.

42. Roleira FMF, et al.: Plant derived and dietary phenolic antioxidants: Anticancer properties. Food Chem 2015;183:235-258.

43. Fernández-Moriano C, Gómez-Serranillos MP, Crespo A: Antioxidant potential of lichen species and their secondary metabolites. A systematic review. Pharm Biol 2015;54:1-17.

44. Costa G, Francisco V, Lopes MC, Cruz MT, Batista MT: Intracellular signaling pathways modulated by phenolic compounds: Application for new anti-inflammatory drugs discovery. Curr Med Chem 2012;19:2876-2900.

45. Wang G, et al:: The JAK2/STAT3 and mitochondrial pathways are essential for quercetin nanoliposome-induced C6 glioma cell death. Cell Death Dis 2013;4:e746.

46. Moretti E, et al.: Effect of quercetin, rutin, naringenin and epicatechin on lipid peroxidation induced in human sperm. $\underline{\text { Reprod }}$ Toxicol 2012;34:651-657.

47. Awad N. et al.: N-acetyl-cysteine (NAC) attenuates LPS-induced maternal and amniotic fluid oxidative stress and inflammatory responses in the preterm gestation. Am J Obstet Gynecol 2011; 204:450.e15-e20.

48. Wang H, et al:: N-Acetylcysteine attenuates lipopolysaccharideinduced apoptotic liver damage in D-galactosamine-sensitized mice. Acta Pharmacol Sin 2007;28:1803-1809.
49. Zhou R, Yazdi AS, Menu P, Tschopp J: A role for mitochondria in NLRP3 inflammasome activation. Nature 2011;469: 221-225.

50. Pasquali MAB, et al.: Retinol and retinoic acid modulate catalase activity in Sertoli cells by distinct and gene expressionindependent mechanisms. Toxicol In Vitro 2008;22:1177-1183.

51. Gelain DP, et al.: Retinol increases catalase activity and protein content by a reactive species-dependent mechanism in Sertoli cells. Chem Biol Interact 2008;174:38-43.

52. Bindoli A, Fukuto JM, Forman HJ: Thiol chemistry in peroxidase catalysis and redox signaling. Antiox Redox Signal 2008;10: 1549-1564.

53. Winterbourn CC, Hampton MB: Thiol chemistry and specificity in redox signaling. Free Radic Biol Med 2008;45:549-561.

54. Bourdon E, Blache D: The importance of proteins in defense against oxidation. Antioxid Redox Signal 2001;3:293-311.

55. Cheng $\mathrm{X}, \mathrm{Ku} \mathrm{CH}$, Siow RCM: Regulation of the Nrf2 antioxidant pathway by microRNAs: New players in micromanaging redox homeostasis. Free Radic Biol Med 2013;64:4-11.

56. Chapple SJ, Siow RCM, Mann GE: Crosstalk between Nrf2 and the proteasome: Therapeutic potential of Nrf2 inducers in vascular disease and aging. Int J Biochem Cell Biol 2012;44:1315-1320.

57. Veit F, Pak O, Brandes RP, Weissmann N: Hypoxia-dependent reactive oxygen species signaling in the pulmonary circulation: Focus on ion channels. Antioxid Redox Signal 2015;22:537-552.

58. Höhn TJA, Grune T: The proteasome and the degradation of oxidized proteins: Part II-protein oxidation and proteasomal degradation. Redox Biol 2013;2:99-104.

59. Höhn TJA, Grune T: The proteasome and the degradation of oxidized proteins: Part III-redox regulation of the proteasomal system. Redox Biol 2014;2:388-394.

60. Grune T, Merker K, Sandig G, Davies KJA: Selective degradation of oxidatively modified protein substrates by the proteasome. Biochem Biophys Res Commun 2003;305:709-718.

61. Davies KJA: Degradation of oxidized proteins by the $20 \mathrm{~S}$ proteasome. Biochimie 2001;83:301-310.

62. Gelain DP, et al:: Serum heat shock protein 70 levels, oxidant status, and mortality in sepsis. Shock 2011;35:466-470.

63. Andrades MÉ, et al.: Plasma glycation levels are associated with severity in sepsis. Eur J Clin Invest 2012;42:1055-1060.

64. Shon W-J, Lee Y-K, Shin JH, Choi EY, Shin D-M: Severity of DSS-induced colitis is reduced in Ido1-deficient mice with downregulation of TLR-MyD88-NF-kB transcriptional networks. $\underline{S c i}$ Rep 2015;5:17305.

65. Tilstra JS, et al.: Pharmacologic IKK/NF- $\kappa \mathrm{B}$ inhibition causes antigen presenting cells to undergo TNF $\alpha$ dependent ROSmediated programmed cell death. Sci Rep 2014;4:3631.

66. Georgopoulos NT, et al:: A novel mechanism of CD40-induced apoptosis of carcinoma cells involving TRAF3 and JNK/AP-1 activation. Cell Death Differ 2006;13:1789-1801.

67. Freund A, Orjalo AV, Desprez P-Y, Campisi J: Inflammatory networks during cellular senescence: Causes and consequences. Trends Mol Med 2010;16:238-246.

68. Ryter SW, Xi S, Hartsfield CL, Choi AMK: Mitogen activated protein kinase (MAPK) pathway regulates heme oxygenase-1 gene expression by hypoxia in vascular cells. Antioxid Redox Signal 2002;4:587-592.

69. Gaestel M, Kotlyarov A, Kracht M: Targeting innate immunity protein kinase signalling in inflammation. Nat Rev Drug Discov 2009;8:480-499. 
This article has been cited by:

1. Mohd Iqbal Yatoo, Archana Saxena, Arumugam Gopalakris, Mahmoud Alagawany, Kuldeep Dhama. 2017. Promising Antidiabetic Drugs, Medicinal Plants and Herbs: An Update. International Journal of Pharmacology 13:7, 732-745. [Crossref] 